\title{
Modeling of food safety knowledge, attitude, and behavior characteristics
}

\author{
${ }^{1}$ Ellinda-Patra, M.W., ${ }^{2,3 *}$ Dewanti-Hariyadi, R. and ${ }^{2}$ Nurtama, B. \\ ${ }^{1}$ Food Technology Study Program, Graduate School of Bogor Agricultural University, Bogor, Indonesia \\ 16680 \\ ${ }^{2}$ Department of Food Science and Technology, Bogor Agricultural University, Bogor, Indonesia 16680 \\ ${ }^{3}$ Southeast Asia Food Agricultural Science and Technology (SEAFAST) Center, Bogor Agricultural \\ University, Bogor, Indonesia 16680
}

\begin{abstract}
Article history:
Received: 9 November 2019 Received in revised form: 14 January 2020

Accepted: 16 January 2020 Available Online: 20 March 2020
\end{abstract}

Keywords:

Food safety,

Knowledge

Attitude

Behavior,

Structural-equation modeling

DOI:

https://doi.org/10.26656/fr.2017.4(4).375

\section{Introduction}

Indonesia Food Law Number 18 of 2012 states that food safety is a major aspect that has to be fulfilled in foods consumed by the public. Consumption of unsafe foods can cause food poisoning. In 2016-2017, there were 167 news of food poisoning and 113 foodborne outbreaks reported in Indonesia (NADFC, 2016a; NADFC, 2017). Based on the news and reports, the foods implicated in the outbreaks were those from the households, street vendors, home industries, and caterings/food services. Outbreaks caused by household foods indicated that people did not understand and apply food safety practices appropriately (NADFC, 2017). To improve knowledge, attitude, and practices of food safety in selected communities, the government of Indonesia through The National Agency of Drug and Food Control (NADFC) initiated community empowerment on food safety for both rural and urban communities. The program has been carried out since 2015 in 33 provinces. The general objectives of this program were to encourage communities to provide safe food and strengthen the communities' economy. Meanwhile, the specific objectives were to increase food safety knowledge, attitude, and behavior; enhance the food safety practices implementation amongst food businesses, and encourage the replication of similar food safety activities in the villages (NADFC, 2016b). The communities involved in the activities include food businesses, food merchants, school communities, nonformal organizations, and health centers.

The indicators for the above program were the number of intervened communities and trained food safety cadres (NADFC, 2015), which reached 40.608 community members and 4.266 food safety cadres 
(NADFC, 2018). However, these indicators do not reflect food safety knowledge, attitude, and behavior of the intervened communities. Thus, there was a need to conduct a study to see the relationships between food safety knowledge, attitude, and behavior after the intervention.

Gefen et al. (2011) stated that according to the neuroscience techniques, latent variables such as beliefs, intentions, and feelings are theoretical constructs that can not be measured directly; and can only be measured through the related characteristics. Several studies have measured knowledge, attitude, and behavior indirectly through their respective characteristics and showed that those three variables are latent variables. Generally, studies on the three variables are also conducted by the bivariate approach thus does not describe the relationships between the variables. A more appropriate method to analyze such variables is the multivariate approach, such as the Structural Equation Modeling (SEM). As the second generation multivariate analysis technique, SEM combines factor analysis and path analysis. SEM is also able to analyze the relationships of multiple latent independent and dependent variables, each of which with many indicators. SEM has been used in recent studies to determine the characteristics and relationships of food safety knowledge, attitude, and behavior of several communities.

The need for studying the relationship between food safety knowledge, attitude, and behavior in the communities intervened by the NADFC program then can be carried out by modeling food safety knowledge, attitude and behavior using SEM approach. This study aimed to describe the demographic characteristics of respondents, determine the correlations between respondents' demographic characteristics and food safety knowledge, attitude, and behavior; determine the indicators of knowledge, attitude, and behavior as the characteristics related to food safety; and obtain a model of the relationships between food safety knowledge, attitude, and behavior of the intervened communities.

\section{Materials and methods}

\subsection{Respondents}

Respondents were purposively chosen from the participants of the community empowerment program on food safety in DKI Jakarta province from 2015 to 2018. The respondents were categorized as housewives, street food vendors, home-industries, and food retailers communities. The criteria for the housewives are married women, divorcée or widows who do not work in the formal sector. Street food vendors are men or women who process ready-to-eat foods for sale, including foods sold in food stalls. Home-industry communities are men or women who process low risk packaged food with a shelf-life of more than 7 days. The criteria for food retailers are men or women, owners or workers in food retailers.

\subsection{Questionnaire}

The questionnaire consisted of four parts, i.e. (1) demographic characteristics, (2) food safety knowledge aspects, (3) food safety attitude aspects, and (4) food safety behaviour aspects. Part 1 was used to collect respondents' name, address, age, sex, education, and net monthly income. Part 2 consisted of 15 right or wrong statements about food safety definition and regulation (2 statements), raw material and water (4 statements), personal hygiene (3 statements), food storage (4 statements), food-borne disease (1 statement), and kitchenware hygiene and sanitation (1 statement). Each correct answer was given 1 point and incorrect answers were given 0 . Part 3 consisted of 8 statements with 5 points Likert-scale answers, from strongly agree (0 point) to strongly disagree (5 points) that covered raw material and water (3 statements), personal hygiene (2 statements), food storage (2 statements), and kitchenware hygiene and sanitation ( 1 statement). Part 4 consisted of 6 statements with 5 points Likert-scale answers, from practiced every day ( 0 point) to never practiced (5 points), about raw material and water (1 statement), personal hygiene (2 statements), food storage (2 statements), and kitchenware hygiene and sanitation (1 statement). The questionnaire was tried to 37 respondents living in Cibubur, East Jakarta and revised when not easily understood by the respondents. The revised questionnaire consisted of 29 statements. The questionnaire was written in the Indonesian language.

\subsection{Data collection}

Each respondent answered the questionnaire independently and took about 15-20 minutes to complete the questionnaire. The data collection relied fully on the self-assessment of the respondents.

\subsection{Data analysis}

\subsubsection{Analysis of demographic profiles}

Descriptive analysis was used to compose respondents' demographic profiles, consisted of percentages per age group, gender, education level, and net income.

\subsubsection{Validity and reliability tests of the questionnaire statements}

The validity test for questionnaire statements regarding food safety knowledge (part 2) was conducted 
by the biserial correlation test (MS Excel 97-2003). The validity test for questionnaire on attitude and behavior statements (part 3 and 4) were performed by corrected item-total correlation method at $95 \%$ confidence level ( $\alpha$ $=0.05$ ) by PASW Statistics 18 . The reliability tests in each part were based on Cronbach's Alpha. The statements were reliable when the Cronbach's Alpha is > 0.5 . Based on the validity and reliability tests, all the statements were valid and reliable (Cronbach's Alpha of knowledge, attitude, and behavior were $0.54 ; 0.58$; and 0.74 respectively).

\subsubsection{Correlation analysis between demographic} characteristics and food safety knowledge, attitude, and behavior

The correlation analysis was conducted based on the respective scores of knowledge, attitude, and behavior by Pearson correlation (PASW Statistics 18), at 95\% confidence level (significant if the p-value $<0.05$ ).

2.4.4 Modeling to determine knowledge, attitude, and behavior characteristics and relationships

The modeling was done by Smartpls application version 3.2.8 and the results were evaluated based on the outer and inner models. The outer model describes the relationships between variables (knowledge, attitude, and behavior) and their valid statements. A statement will be a characteristic when its outer loading is $>0.5$. The inner model describes the relationships between the three variables. The description of the inner model will also test the hypothesis (Figure 1). The modeling steps, i.e. draw a model hypothesis, place valid statements of the variables, calculate the "Consistent PLS algorithm", remove statements with outer loading $<0.5$; recalculate "Consistent PLS algorithm", and finally run "Consistent Bootstrapping PLS". A relationship is significant if the $p$ -value is $<0.05$.

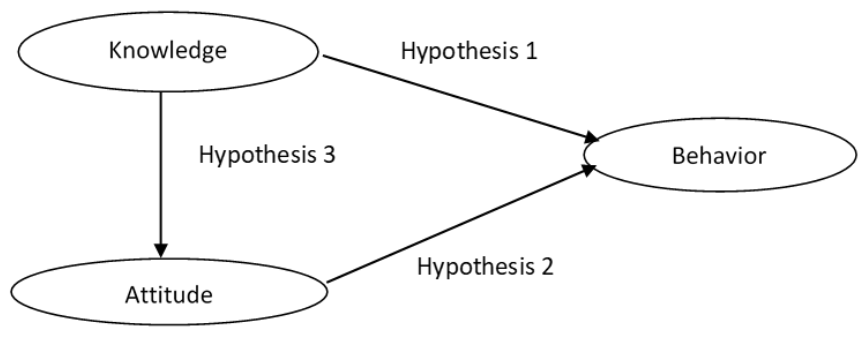

Figure 1. Hypothesis model (Schwartz, 1975)

\section{Results and discussion}

\subsection{Demographic profile of respondents}

Of the 254 respondents, 69 were housewives $(27.16 \%), 67$ were street food vendors $(26,38 \%), 54$ were home-industries workers $(21.26 \%)$, and 64 were food retailers $(25.20 \%)$. The female respondents accounted for $77.17 \%$ of the total respondents due to a large number of housewives communities participating in this study. The largest age group of female respondents was $41-50$ years old $(45.41 \%)$, followed by $51-60$ years old $(22.45 \%)$ and $31-40$ years old $(19.90 \%)$, while for male respondents was 41-50 years old (36.21\%), followed by $31-40$ years old (32.76\%), and 51 -60 years old $(13.79 \%)$. Although there were differences in the proportions in each age group, the 41-50 years old respondents were dominant both in women and men.

Women and men respondents having a net income of below Rp. 2 million/month were 52,04\% and 46,55\% respectively. Based on The National Social Economic Survey September 2017 (DKI-Jakarta, 2018), this amount is close to The Provincial Minimum Wage in DKI Jakarta Province, which is Rp 3.940.973,096 per month. Around one-third of respondents had net income of Rp 2-4 million per month thus more than $80 \%$ of respondents had an income of 1-2 times minimum wage in DKI Jakarta. Women had higher education but similar income as compared to men, possibly since female respondents tended to work for an additional income, not as the primary source of income in a family (Muyanja et $a l ., 2011)$. The demographic profile of the respondents is illustrated in Figure 2.

In general, the level of education of female respondents in this study was higher than male, similar to the female primary education profile of DKI Jakarta but different from the male's education profile (CBS-RI, 2018). This suggests an increase in the number of literate women that could improve the ability of women to absorb science and technology and impact on the level of welfare of women as the members of a community. Education will affect mothers' patterns in educating and taking care of their children, gradually impacts the general level of community welfare, and finally impact the quality of future generations (CBS-RI, 2018). Male respondents were generally younger and had lower education than the female respondents, indicating that male respondents did not continue their education to a higher level and worked in the nonformal sector immediately after completing their primary education.

\subsection{The correlations between respondents' demographic characteristics and food safety knowledge, attitude, and behavior}

The food safety level of knowledge, attitude, and behavior were classified as good, i.e. more than 95\%, following studies by Ansari-Lari et al. (2010) and Abdul -Mutalib et al. (2012). The Pearson correlation test results between the demographic characteristics and food safety knowledge, attitude, and behavior are presented in Table 1 . The result suggested that the type of community 


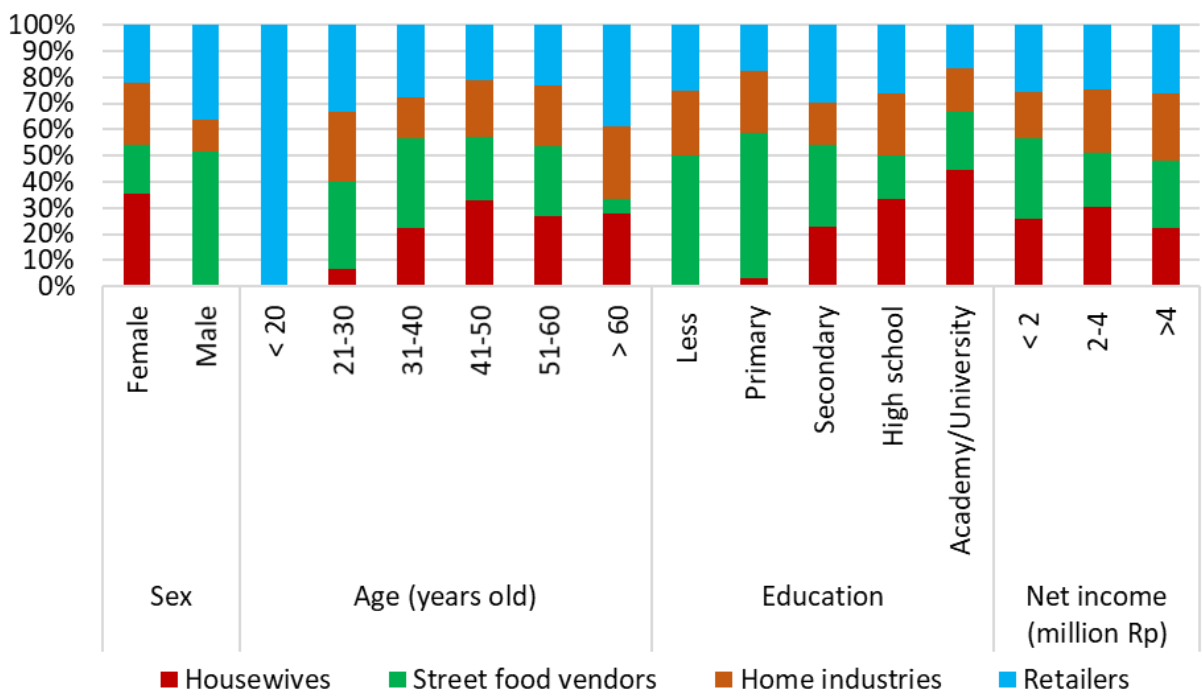

Figure 2. The demographic profile of respondents

Table 1. Pearson correlation test results

\begin{tabular}{cccc}
\hline \multirow{2}{*}{$\begin{array}{c}\text { Demographic } \\
\text { characteristics }\end{array}$} & \multicolumn{3}{c}{ Correlation with } \\
\cline { 2 - 4 } & Knowledge & Attitude & Behavior \\
\hline Communities & -0.038 & -0.02 & 0.044 \\
Age & -0.044 & -0.051 & 0.008 \\
Sex & -0.074 & -0.088 & -0.063 \\
Education & $0.147^{*}$ & $0.152^{*}$ & 0.062 \\
Nett income & 0.071 & $0.132^{*}$ & 0.012 \\
\hline
\end{tabular}

* significant at confidence level $(\alpha=0.05)$

did not correlate with food safety knowledge, attitude, or behavior. The respondents of this study were the NADFC food safety program participants and each of them received the same food safety material in general. This condition could be the cause of the absence of correlation of food safety knowledge, attitude, and behavior, even among food retailer respondents who had no direct contact with food. This result indicates that as long as the respondents received the same information, counseling, and assistance regardless of their gender and age, the level of knowledge, attitude, and behavior would not be significantly different. Education significantly correlated with knowledge and attitude of food safety but did not significantly correlate with food safety behavior. This result was also similar to Abdul-Mutalib et al. (2012), Soares et al. (2012), Liu et al. (2013), and Farahat et al. (2015). According to Ruby et al. (2019a), education level was a demographic characteristic that differentiates the level of food safety knowledge, as well as gender, age, number of children, and food preparation frequency. Tertiary level education and female gender were significant predictors of food safety knowledge. In our study, education was the only characteristic which correlates with food safety knowledge. However, the number of tertiary-educated respondents in this research was very low $(7.09 \%)$. The net income of the respondents significantly correlated with food safety attitude but did not significantly correlate with the food safety knowledge and behavior. These results were similar to Liu et al. (2013) who concluded that income was a factor related to food safety (behavior). For people with limited or low income, price is an important factor in buying foods compared to those with higher incomes (Dammann and Smith, 2009).

\subsection{The statement characteristics for food safety knowledge, attitude, and behavior}

Based on the model established in this study, several statements are determined as the characteristics for food safety knowledge, attitude, and behavior, i.e. one statement for food safety knowledge (code PU06), 3 statements for food safety attitude (code SU02, SU03, and SU05), and 6 statements for food safety behavior (code RU01 until RU06), as described in Table 2. Knowledge characteristic PU06 was related to the distribution permits for ready-to-eat foods. The average value of respondents' answers was $0.24 \pm 0.027$, meaning that only 1 of 4 respondents could answer correctly. According to Government Regulation No. 28/2004 on Food Safety, Quality and Nutrition (MoSS, 2004), processed foods with a shelf life of fewer than seven days at room temperature (ready-to-eat food category) were exempted from the mandatory for the distribution permits. The result of this study indicates that respondents assume that all category of food should have distribution permits.

Characteristic statements SU02 and RU05 were associated with the consumption of unboiled refill drinking water. Recently, there is an increase in the demand for drinking water but not accompanied by adequate supply. The percentage of households in DKI Jakarta consuming bottled drinking water and refill water had increased from $4.32 \%$ in 2000 to $72.31 \%$ in 2016 (CBS-RI, 2019). Unfortunately, several studies suggested that refill water was susceptible to microbial 
Table 2. The statement characteristics for food safety knowledge, attitude, and behavior

\begin{tabular}{|c|c|c|c|c|}
\hline Variables & Code & Descriptions & Outer loading & p-value \\
\hline Knowledge & PU06 & Ready-to-eat food must have distribution permits & 1 & 0 \\
\hline \multirow{3}{*}{ Attitude } & SU02 & Water from refill depots is safe to consume directly without boiling & 0.544 & 0 \\
\hline & SU03 & Washing hands with water only without soap is adequate & 0.715 & 0 \\
\hline & SU05 & Sneezing without covering your mouth and nose towards food is correct & 0.553 & 0 \\
\hline \multirow{6}{*}{ Behavior } & RU01 & $\begin{array}{l}\text { I use the same cloth to wipe the dishes, wipe the hands, and wipe the table (one } \\
\text { cloth for all) }\end{array}$ & 0.664 & 0 \\
\hline & RU02 & I do not wash my hands after I use the bathroom & 0.594 & 0 \\
\hline & RU03 & I do not close food containers tightly & 0.545 & 0 \\
\hline & RU04 & I store pasteurized milk at room temperature for a long time & 0.58 & 0 \\
\hline & RU05 & I drink refill-water without boiling prior to consumption & 0.611 & 0 \\
\hline & RU06 & I sneeze toward food without covering my nose and mouth & 0.502 & 0 \\
\hline
\end{tabular}

contamination, i.e. coliforms (Walangitan et al., 2016; Hilmarni et al., 2018), Bacillus subtilis (Rumondor et al., 2014), Klebsiella pneumonia and Pseudomonas aerogenosa (Birawida et al., 2018), and Escherichia coli (Apriliana et al., 2014; Walangitan et al., 2016). Thus, it is recommended to reduce microbial contamination by boiling (Septiani et al., 2018).

Characteristic statements pertaining to food safety attitude SU03 and food safety behavior RU02 were related to hand washing. "Handwashing" is an effective way to inhibit the spread of microorganisms. Other studies using SEM also concluded "handwashing" as an indicator for food safety knowledge (Lim et al., 2016) and food safety behavior (Baser et al., 2016). Food safety characteristics of attitude SU05 and behavior RU06 were related to preventing contamination by covering nose and mouth when sneezing and coughing. The characteristic was not determined as a food safety indicator in previous studies using SEM (Ko, 2013, Baser et al., 2016; Lim et al., 2016). However, the statement had been used in other studies on food safety knowledge, attitude, and behavior. Tegegne and Phyo (2017), Agüeria et al. (2018), and Prabhusaran et al. (2018) suggested that respondents who answered correctly pertaining the habit of covering nose and mouth when sneezing and coughing would generally have good attitude.

Food safety behavior statement characteristic RU01 was associated with the use of kitchen cloths for multiple purposes. Previous studies suggested that kitchen wipes could be a source of coliform contamination (Oxford et al., 2013; Gil et al., 2014), E. coli, Enterobacteriaceae as well as Pseudomonas spp. (Gil et al., 2014). Additionally, the environment could also become a source of contamination. Therefore, processed food must be stored in closed containers (characteristic RU03) and safe temperatures (characteristic RU04). An example to characteristic RU04 is preventing post pasteurization contamination by storing pasteurized milk at lower temperatures, which is a key in producing safe pasteurized milk, thus storage of pasteurized milk at room temperature should be avoided. This result was supported by Ruby et al. (2019b) who reported that keeping cooked food at a safe temperature was an indicator of food safety attitude.

$3.4 \mathrm{~A}$ model for the relationships between food safety knowledge, attitude, and behavior of the intervened communities

The analysis using PLS-SEM showed that the path coefficient for food safety knowledge and behavior was 0.169 (p-value $<0.05$ ) suggesting that food safety knowledge affects food safety behavior. This result indicated the importance of developing food safety knowledge improvement programs to improve food safety behavior among communities. The result was similar to Abdul-Mutalib et al. (2012), Lim et al. (2016) and Al-Shabib et al. (2017).

The path coefficient for food safety attitude and behavior was 0.223 ( $\mathrm{p}$-value $>0.05$ ) thus food safety attitude does not affect food safety behavior. The result was different from Abdul-Mutalib et al. (2012), Rahman et al. (2016) and Lim et al. (2016) who suggested that the food safety attitude would affect food safety behavior. One theory related to attitude and behavior is the Theory of Planned Behavior, which postulates three conceptually independent determinants of intention or important factors that transform an attitude into behavior. The three factors are intention or attitude, perceived social pressure, and perceived behavioral control (Ajzen, 1991). The first factor, intention or attitude, denotes the need for a good attitude to encourage good behavior. A person will perform certain behavior (action) if she/he has a positive attitude towards a subject. In this research, the respondents had a good attitude as shown by the high percentage of the food safety attitude level thus they will have good behavior. The second postulate states that perceived social pressure, or subjective norm, will affect 
one's intention or attitude positively. A person most likely will perform an intention if the people around him/ her have the same attitude because he/she will try to fulfill the surrounding people's expectations, e.g. parents or other family members, in practicing food safety (Mullan et al. 2013; Ruby et al. 2019b). Ruby et al. (2019b) determined that subjective norm was the strongest factor, amongst others e.g attitude and perceived social behavior, in driving someone's intention of food safety. The third factor is perceived behavioral control (PBC), i.e. how easy the behavior to be done. If the behavior is easy to be done, there is a greater chance for someone to implement it. For example, based on this research, low-income communities will likely face difficulties in choosing safe foods because they cannot afford the price. Thus, food safety behavior would not be expressed. The role of $\mathrm{PBC}$ in affecting intention was studied previously by Ruby et al. (2019b) who concluded that PBC was a significant predictor in food handling intentions.

The path coefficient of food safety of knowledge and attitude was 0.363 ( $\mathrm{p}$-value $<0.05$ ) suggesting that food safety knowledge affects food safety attitude. This result is in accord with studies by Abdul-Mutalib et al. (2012), Al-Shabib et al. (2017), and Ruby et al. (2019b). AbdulMutalib et al. (2012) stated that that good knowledge could lead to a good attitude, while a study by AnsariLari et al. (2010) found that there was a significant positive correlation between knowledge and attitude. This result indicated the need to improve food safety knowledge as a strong foundation to establish food safety attitude. The model for food safety knowledge, attitude, and behavior are illustrated in Figure 3.

\section{Conclusion}

This study concludes that there is no correlation between community, age, and gender with food safety knowledge, attitude, and behavior. Conversely, there is a significant correlation between education and food safety knowledge and attitude, and between net income and food safety attitude.

The statement characteristics for food safety knowledge, attitude, and behavior are those related to food distribution permits, refill water safety, personal hygiene, kitchen equipment hygiene, and food-storage. Food safety knowledge affects food safety attitude and behavior significantly. Therefore, there is a need to improve food safety knowledge in order to improve food safety attitude and behavior of the communities. Food safety attitude does not affect food safety behavior significantly. Based on the Theory of Planned Behavior, there may be other factors that drive changes in behavior such as perceived social pressure and behavioral control.

\section{Conflict of Interest}

The first author works at and has received a scholarship from The National Agency of Drug and Food Control (NADFC). The second and third authors declare no potential conflict of interest.

\section{Acknowledgments}

The authors would like to express their gratitude to The National Agency of Drug and Food Control (NADFC) Republic of Indonesia for the research supports.

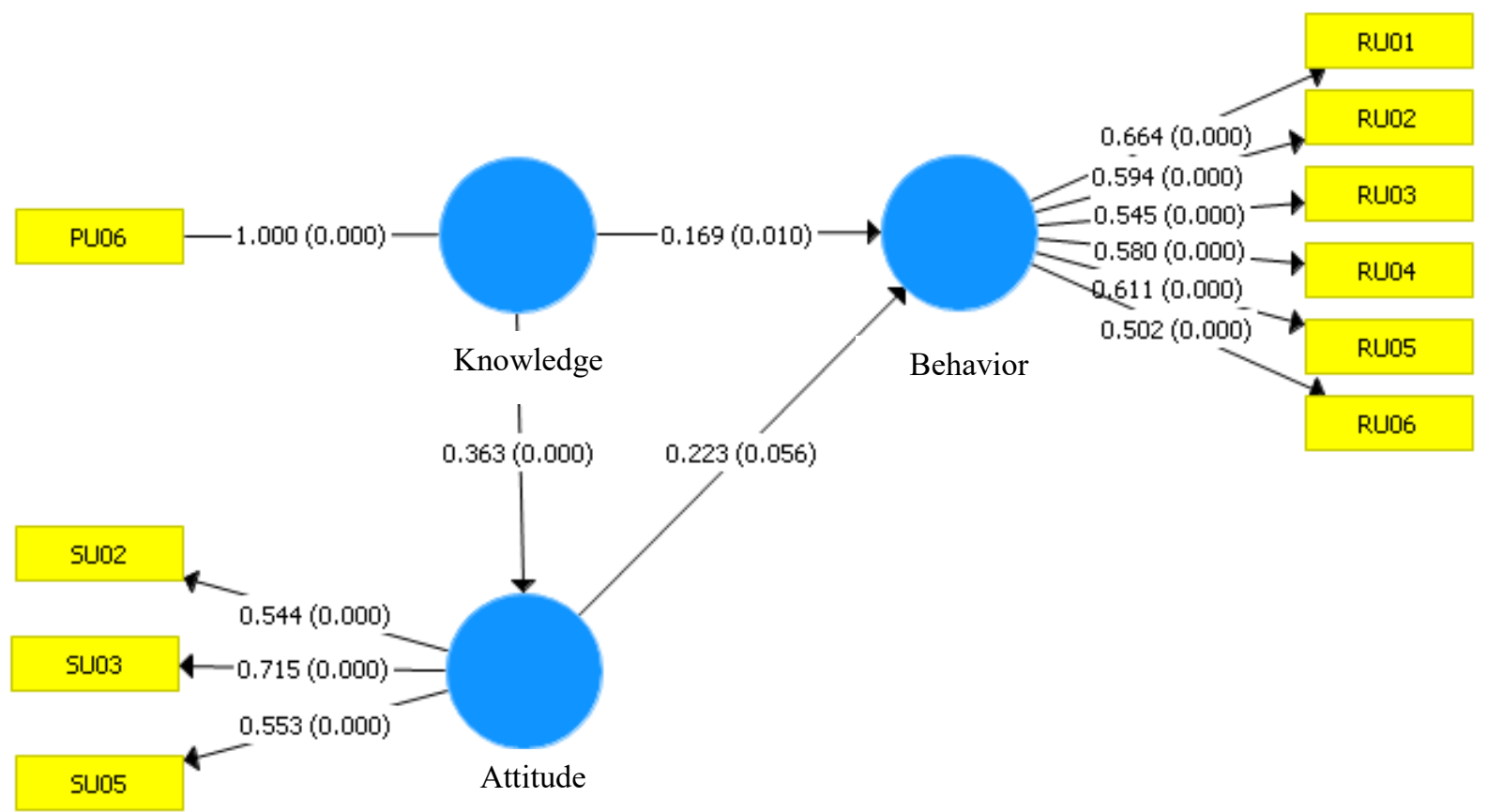

Figure 3. The model of food safety knowledge, attitude, and behavior 


\section{References}

Abdul-Mutalib, N.A., Abdul-Rashid, M.F., Mustafa, S., Amin-Nordin, S., Hamat, R.A. and Osman, M. (2012). Knowledge, attitude and practices regarding food hygiene and sanitation of food handlers in Kuala Pilah, Malaysia. Food Control, 27(2), 289293. https://doi.org/10.1016/j.foodcont.2012.04.001

Agüeria, D.A., Terni, C., Baldovino, V.M. and Civit, D. (2018). Food safety knowledge, practices and attitudes of fishery workers in Mar del Plata, Argentina. Food Control, 91, 5-11. https:// doi.org/10.1016/j.foodcont.2018.03.028

Ajzen, I. (1991). The theory of planned behavior. Organizational Behavior and Human Decision Processes, 50(2), 179-211. https:// doi.org/10.1016/0749-5978(91)90020-T

Al-Shabib, N.A., Husain, F.M. and Khan, J.M. (2017). Study on food safety concerns, knowledge and practices among university students in Saudi Arabia. Food Control, 73(Part B), 202-208. https:// doi.org/10.1016/j.foodcont.2016.08.005

Ansari-Lari, M., Soodbakhsh, S. and Lakzadeh, L. (2010). Knowledge, attitudes and practices of workers on food hygienic practices in meat processing plants in Fars, Iran. Food Control, 21(3), 260-263.

https://doi.org/10.1016/

j.foodcont.2009.06.003

Apriliana, E., Ramadhian, M.R. and Gapila, M. (2014). Bacteriological quality of refill drinking water at refill drinking water depots in Bandar Lampung. Juke Universitas Lampung, 4(7), 142-146.

Baser, F., Ture, H., Abubakirova, A., Sanlier, N. and Cil, B. (2016). Structural modeling of the relationship among food safety knowledge, attitude and behavior of hotel staff in Turkey. Food Control, 73(Part B), 438-444. https://doi.org/10.1016/ j.foodcont. 2016. 08.032

Birawida, A., Selomo, M. and Mallongi, A. (2018). Potential hazards from hygiene, sanitation and bacterium of refill drinking water at Barrang Lompo island (water and food safety perspective). IOP Conference Series: Earth and Environmental Science, 157, 012034. https://doi.org/10.1088/17551315/157/1/012034

Central Bureau of Statistics Republic of Indonesia (CBSRI). (2018). Education Profile Of DKI Jakarta Province in 2017. Retrieved on November 18, 2019 from CBS Website: https://jakarta.bps.go.id/ publication/2018/05/30/1bc7d0dfb2c2728ec4d15cdc /profil-pendidikan-provinsi-dki-Jakarta2017.html

Central Bureau of Statistics Republic of Indonesia (CBSRI). (2019). Percentage of Households by Province and Drinking Water Source 2000-2016. Retrieved on August 19, 2019 from CBS Website: www.bps.go.id/statictable/2014/09/10/1361/ persentase-rumah-tangga-menurut-provinsi-dan sumber-air-minum-2000-2016.html.

Dammann, K.W. and Smith, C. (2009). Factors affecting low-income women's food choices and the perceived impact of dietary intake and socioeconomic status on their health and weight. Journal of Nutrition Education and Behavior, 41(4), 242-253. https:// doi.org/10.1016/j.jneb.2008.07.003

Farahat, M.F., El-Shafie, M.M. and Waly, M.I. (2015). Food safety knowledge and practices among Saudi women. Food Control, 47, 427-435. https:// doi.org/10.1016/ j. foodcont.2014.07.045

Gefen, D., Straub, D.W. and Rigdon, E.E. (2011). An update and extension to SEM guidelines for admnistrative and social science research. Management Information System Quarterly, 35, 314. www.jstor.org/ stable/pdf/ 23044042.pdf?seq=1/ subjects

Gil, A. I., Lanata, C.F., Hartinger, S.M., Mäusezahl, D., Padilla, B., Ochoa, T.J., Lozada, M., Pineda, I. and Verastegui, H. (2014). Fecal contamination of food, water, hands, and kitchen utensils at the household level in rural areas of Peru. Journal of Environmental Health, 76, 102-107. http:// www.jstor.org/stable/ 26329963

Hilmarni, H., Ningsih, Z. and Ranova, R. (2018). Coliform bacterial contamination in refill drinking water from Tarok Dipo village depot in Bukittinggi, presented at Seminar Kesehatan Perintis, Padang, Indonesia: STIKes Perintis PADANG.

Indonesia Ministry of State Secretariat (MoSS). (2004). Government Regulation Number 28 concerning Food Safety, Quality and Nutrition, Jakarta, Indonesia: MoSS.

Ko, W.H. (2013). The relationship among food safety knowledge, attitudes and self-reported HACCP practices in restaurant employees. Food Control, 29 (1), 192-197. https://doi.org/10.1016/ j.foodcont.2012.05.076

Lim, T.P., Chye, F.Y., Sulaiman, M.R., Suki, N.M. and Lee, J.-S. (2016). A structural modeling on food safety knowledge, attitude, and behaviour among Bum Bum Island community of Semporna, Sabah. Food Control, 60, 241-246. https://doi.org/10.1016/ j.foodcont.2015.07.042

Liu, R., Pieniak, Z. and Verbeke, W. (2013). Consumers' attitudes and behaviour towards safe food in China: A review. Food Control, 33(1), 93-104. https:// doi.org/10.1016/j.foodcont.2013.01.051 
Local Goverment of DKI Jakarta Province (DKIJakarta). (2018). Governor Regulation Number 114 Year 2018 Concerning Provincial Minimum Wage Year 2019. Retrieved on November 18, 2019 from DKI-Jakarta Website: https://jdih.jakarta.go.id/ uploads/default/produkhukum/Pergub_No._114_ Tahun_2018.pdf

Mullan, B.A., Wong, C. and Kothe, E.J. (2013). Predicting adolescents' safe food handling using an extended theory of planned behaviour. Food Control, 31(2), 454-460. https://doi.org/10.1016/ j.foodcont.2012.10.027

Muyanja, C., Nayiga, L., Brenda, N. and Nasinyama, G. (2011). Practices, knowledge and risk factors of street food vendors in Uganda. Food Control, 22 (10), 1551-1558. https://doi.org/10.1016/ j.foodcont.2011.01.016

National Agency of Drug and Food Control Republic of Indonesia (NADFC). (2015). Regulation of the Head of the Republic of Indonesia Drug and Food Supervisory Agency Number 24 of 2015 concerning The Food Safety Empowerment of the Urban Communities, Jakarta, Indonesia: NADFC

National Agency of Drug and Food Control Republic of Indonesia (NADFC). (2016a). Annual Report 2016. Retrieved on November 18, 2019 from NADFC Website: https://www.pom.go.id/new/admin/ dat/20171127/laptah2016.pdf

National Agency of Drug and Food Control, Republic of Indonesia. (2016b). Guidelines for Urban Communities Empowerment of Food Safety, Jakarta, ID: NADFC

National Agency of Drug and Food Control Republic of Indonesia (NADFC). (2017). Annual Report 2017. Retrieved on November 18, 2019 from NADFC Website: https://www.pom.go.id/new/admin/ dat/20180710/Laporan\%20Tahunan\%20BPOM\% 202017.pdf

National Agency of Drug and Food Control, Republic of Indonesia. (2018). Annual Report 2018. Retrieved on November 18, 2019 from NADFC Website: https:// www.pom.go.id/new/admin/dat/20191212/LAPTAH -BPOM-2018.pdf

Oxford, J., Berezin, E.N., Courvalin, P., Dwyer, D., Exner, M., Jana, L.A., Kaku, M., Lee, C., Letlape, K. and Low, D.E. (2013). An international survey of bacterial contamination and householders' knowledge, attitudes and perceptions of hygiene. Journal of Infection Prevention, 14(4), 132-138. https://doi.org/10.1177/1757177413483346

Prabhusaran, N., Manivannan, L., Pramila, M. and Prabhakar, Y. (2018). Knowledge, Attitude and
Practice of personal hygiene, cleaning and sanitation during food processing. European Journal of Pharmaceutical and Medical Research, 5, 455-461.

Rahman, M.M., Arif, M.T., Bakar, K. and Talib, Z. (2016). Food safety knowledge, attitude and hygiene practices among the street food vendors in Northern Kuching City, Sarawak. Borneo Science, 31, 107116.

Ruby, G.E., Abidin, U.F.U.Z., Lihan, S., Jambari, N.N. and Radu, S. (2019a). A cross sectional study on food safety knowledge among adult consumers. Food Control, 99, 98-105. https://doi.org/10.1016/ j.foodcont.2018.12.045

Ruby, G.E., Abidin, U.F.U.Z., Lihan, S., Jambari, N.N. and Radu, S. (2019b). Predicting intention on safe food handling among adult consumers: A cross sectional study in Sibu district, Malaysia. Food Control, 106, 106696. (Accepted Version) https:// doi.org/10.1016/j.foodcont.2019.06.022

Rumondor, P.P., Porotu'o, J. and Waworuntu, O. (2014). Identification of bacteria in refill drinking water depots in Manado City. Jurnal e-Biomedik, 2. https://doi.org/10.35790/ebm.2.2.2014.5518

Schwartz, N. (1975). Nutrition knowledge, attitude and practices of high school graduates. Journal of American Dietetic Association, 66(1), 28-31.

Septiani, I., Nurwitri, C.C., Rahayu, W.P. and Indrotristanto, N. (2018). Penentuan Titik Kritis Risiko Mikrobiologi dalam Rantai Penyediaan Minuman Es di Jakarta. Jurnal Mutu Pangan (Indonesian Journal of Food Quality), 5(2), 80-87. [In Bahasa Indonesia].

Soares, L.S., Almeida, R.C., Cerqueira, E.S., Carvalho, J.S. and Nunes, I.L. (2012). Knowledge, attitudes and practices in food safety and the presence of coagulase-positive staphylococci on hands of food handlers in the schools of Camaçari, Brazil. Food Control, 27(1), 206-213. https://doi.org/10.1016/ j.foodcont. 2012. 03. 016

Tegegne, H.A. and Phyo, H. (2017). Food safety knowledge, attitude and practices of meat handler in abattoir and retail meat shops of Jigjiga Town, Ethiopia. Journal of Preventive Medicine and Hygiene, 58, E320-E327. https:/ doi.org/10.15167/2421-4248/jpmh2017.58.4.737

Walangitan, M.R., Sapulete, M.R. and Pangemanan, J.M. (2016). Gambaran kualitas air minum dari depot air minum isi ulang di Kelurahan Ranotana-Weru dan Kelurahan Karombasan Selatan menurut parameter mikrobiologi. Jurnal Kedokteran Komunitas dan Tropik, 4, 49-58. [In Bahasa Indonesia]. 